\title{
Empowerment of tribal women in Ukhrul District, India - the role of IFAD supported SHGs
}

\author{
Pamchuiso Ningshen and M.P.Boraian \\ Department of Extension Education, GRI-Deemed University, Gandhigram-624302, Tamil Nadu, India
}

\begin{abstract}
The aim of this study is to evaluate the women's SHGs under IFAD support in Ukhrul District, the North Eastern Region of Manipur State, India. SHGs in 10 villages of the study area were selected for the study purposively. Data collection methods included survey and analysis of Status Report (UDCRMS/IFAD). The technique used was personal interview with SHG leaders, representatives, and key IFAD staff. The tools comprised an interview schedule. A focus group discussion was also held with the SHGs members at the village level. The results revealed that though the SHGs confounded by many regional complexities, there is a better and faster spread in its growth and development. In the context of Ukhrul District's traditional institution, women do not have much say in decision making and credit is considered as man's domain. However, this position is slowly reversing by means of building the confidence of the individual members through forming SHGs.
\end{abstract}

Keywords: Financial Inclusion, IFAD, Microfinance, North Eastern Region, Self-Help Groups and Tribal women.

\section{Introduction}

Indian society has all along been a male dominated society. For instance, the Human Development Report 2011 of the UNDP shows that in the gender inequality index, India fares poorly, trailing neighborhood Bangladesh and Pakistan, although it is better placed in terms of GNI per capita. Moreover, of the total female population in India, $77 \%$ live in rural areas under poverty. Further, the average rural poverty in NER is 31.17 per cent which is much higher than the India's average of 27.1 percent, clearly implies that various poverty alleviation programmes of the government have not achieved the desired results. Poverty and deprivation increase gender inequality, which favors a policy for empowerment of women by increasing their access to credit through SHGs. Self-help groups aim to "improve the economic, social and educational condition of women" by offering training and bank loans for women's self-employment generation.

Specifically, they provide women with marketing strategies, business knowledge and skills. They are expected to become entrepreneurs and thereby limit the need for state benefits, services, and concessions. However, in the 2012 budget, the centre has also decided to provide loans up to Rs.3 lakh to women SHGs at a subsidized rate of 7 per cent and an additional subsidy of 3 per cent to those who return it promptly. These interventions might be of great help in addressing rural poverty and improving the living standards of the poor.

The International Fund for Agricultural Development (IFAD) works with poor rural men and women to develop locally specific opportunities that enable them to thrive economically in their own communities. It supports self-help groups, community institutions and village development associations in tribal and non-tribal areas that work in synergy with local self-governments. Poor rural women and men in developing countries are empowered to achieve higher incomes and improved food security. They also help them build their knowledge, skills and organizations so that they can lead their own development and influence the decisions and policies that affect their lives.

\section{Socio-economic status of women in Ukhrul District}

The main constituents of the population of Ukhrul District, in the North Eastern Region of Manipur State, India are predominantly of the Tangkhul tribes. The early Tangkhul village state was economically selfsufficient; most of the needs of the numerous villages were produced in the village itself. Each village owned independently cultivated land, salt lake, domestic animals etc. and maintained sufficiency in rice and vegetables. They lived a simple, self-contained and happy life. There was no division of labour as in other Indian villages men had their own pre-occupation and women their's. Agriculture played the most important role in their economy. It was and continues to be the mainstay of the Tangkhul economy incorporated by handicrafts, weaving, pottery, domestication of animals and trade (A.S.W.Shimray, 2001).

The status of women is by no means inferior to that of men in Tangkhul society; so also in their role and contribution they make in social life, both men and women are placed on an equal footing. On women fall 
the duty of domestic activities and cultivation. They work in the fields from the sowing of seeds till the harvests are over. She is usually the first to get up early in the morning for all those works and then goes to the field. In the evening, again, she takes care of all the household works; and she is the last to retire to bed. She should be adorned with modesty and chastity, preserving morality, always ready to listen than to speak. Further, the Tangkhuls, being a patriarchal society, women should be under the control of men.

According to Ibomcha Singh, the economic role of women in the traditional Tangkhul society depends upon two important factors viz; a) the need for augmenting family income and b) Opportunities available for participation in such economic activities. It has been reported that women play a big role in the economic welfare of the family. It is generally felt that the role of women in Tangkhul society is not just confined to the household management but outside job connected with agriculture, market activities such as selling vegetables, selling meat etc. as well as non - market activities.

However, despite some restrictions on women as mentioned, their status is by no means lower than men. All the important matters of a house are discussed with them and their ideas are well accommodated in decision making (A.S.W.Shimray, 2001). Moreover, credit is considered as man's domain. As early as 1890, Elizabeth Cady Stanton stated that; "When women can support themselves, have their entry to all the trades and professions, with a house of their own over their heads and a bank account, they will own their bodies and be dictators in the social realms. But women, in particular, find it hard to accumulate savings because their household responsibilities and kinship obligations mean that something or someone always comes along to make a claim (Khavul, Bruton, \& Wood, 2009; Mayoux, 2001). If a woman is economically unsound and does not have property to mortgage, access to formal credit will never be an opportunity for the secluded rural womenfolk.

\section{Study Area}

This study aimed at evaluation of the IFAD supported women SHGs in Ukhrul District, the North Eastern Region of Manipur, India.

\section{Method of the Study}

SHGs in 10 villages of the study area were selected for the study purposively. Data collection methods included survey and analysis of Status Report (UDCRMS/IFAD, Ukhrul District 1999-2008). The technique used was personal interview conducted among SHG leaders, representatives, and key IFAD staff. The tools comprised an interview schedule. A focus group discussion was also held with the Self Help Group members at the village level. Field visits were made to observe various activities such as SHG meetings, Training programmes, and workshops conducted through the SHGs. The study used Percentages for analysis of the data.

V. Period of the Study

The data presented in this study were collected during 2009 to 2012.

\section{Analysis and Discussion}

Self Help Groups have emerged as a powerful change agent to the rural people. In the following pages, primary data gathered from the SHGs have been analyzed.

Table 1 Shows that the refinance disbursement across regions during the year varied widely with the highest share being in the south $(43 \%)$ followed by north $(21 \%)$, central (14\%), and other regions $(20 \%)$. The North East had the least share of a meager two per cent.

Table 1. Region-wise disbursement of Microfinance in the North East

(Rs in crores)

\begin{tabular}{|l|c|c|c|c|c|c|c|c|c|}
\hline \multirow{2}{*}{ Region } & \multicolumn{3}{|c|}{$2008-09$} & \multicolumn{3}{|c|}{$2009-10$} & \multicolumn{3}{|c|}{$2010-11$} \\
\cline { 2 - 10 } & Target & Disbursed & \%share & Target & Disbursed & \%share & Target & Disbursed & \%share \\
\hline Northern & 2636.00 & 2636.45 & 25.00 & 2790.00 & 2419.87 & 20.20 & 2835.00 & 2810.70 & 20.80 \\
\hline $\begin{array}{c}\text { North } \\
\text { Eastern }\end{array}$ & 174.00 & 174.18 & 1.70 & 210.00 & 139.85 & 1.20 & 266.00 & 265.82 & 2.00 \\
\hline Southern & 1103.00 & 4298.91 & 40.80 & 1185.00 & 5967.89 & 49.70 & 1392.00 & 5821.73 & 43.20 \\
\hline Eastern & 1526.00 & 1102.99 & 10.50 & 1680.00 & 891.07 & 7.40 & 1718.00 & 1405.35 & 10.40 \\
\hline Central & 797.00 & 1526.02 & 14.50 & 935.00 & 1478.60 & 12.30 & 965.00 & 1928.63 & 14.30 \\
\hline
\end{tabular}


Empowerment of tribal women in Ukhrul District, India - The role of IFAD supported SHGs

\begin{tabular}{|c|c|c|c|c|c|c|c|c|c|}
\hline & & & & & & & & \\
\hline Western & 4299.00 & 796.74 & 7.60 & 4500.00 & 1111.79 & 9.30 & 5804.00 & 1253.64 & 9.30 \\
\hline Total & 10535.00 & $10535.29^{*}$ & 100.00 & 11300.00 & $12009.08^{*}$ & 100.00 & 12980.00 & $13485.87^{*}$ & 100.00 \\
\hline
\end{tabular}

(Source: NABARD, Annual Report 2010-2011) *: Includes ST-SAO refinance released to SCARDB

\section{Regions}

Northern:

States and Union Territories coming under the purview of six different regions are listed below:

Chandigarh, Delhi, Haryana, Himachal Pradesh, Jammu \& Kashmir,Punjab and Rajasthan

\section{North Eastern:}

Southern:

Assam, Arunachal Pradesh, Manipur Meghalaya, Mizoram, Nagaland, Tripura and Sikkim,

Eastern:

Andhra Pradesh, Karnataka, Kerala, Puducherry, Tamil Nadu and Lakshwadeep Islands,

\section{Central:}

A\&N Islands, Bihar, Jharkhand, Odisha and West Bengal,

\section{Western:}

Madhya Pradesh, Chhattisgarh, Uttar Pradesh and Uttarakhand,

Dadra \& Nagar Haveli, Daman \& Diu, Goa, Gujarat and Maharashtra

The SHGs have five cluster of Zones namely Western, Eastern, Central, Southern and Northern. Table 2 shows that totally, 209 villages had formed 681 SHGs as on $30^{\text {th }}$ September 2007. Among these, Western zone has the highest number of 190 SHGs and Southern with the least number of 62 SHGs. The Northern Zone shows the highest fund mobilization of Rs.7,140,197 /- whereas Southern Zone shows the lowest fund mobilization of Rs.1, 250, 546/- as compared to Northern, Western, Eastern and Central Zone.

Table 2. Profile of Self help Groups in UDCRMS/IFAD, Ukhrul (As on $3^{\text {th }}$ September, 2007)

\begin{tabular}{|l|l|l|l|l|}
\hline S1.No. & Zone & No. of villages & No. of SHGs & $\begin{array}{l}\text { Total Savings mobilized } \\
\text { (in Rs) }\end{array}$ \\
\hline 1 & Northern & 33 & 140 & $7,140,197$ \\
\hline 2 & Western & 31 & 190 & $5,935,215$ \\
\hline 3 & Eastern & 63 & 139 & $3,586,810$ \\
\hline 4 & Central & 54 & 150 & $3,356,871$ \\
\hline 5 & Southern & 28 & 62 & $1,250,546$ \\
\hline & Total & 209 & 681 & $21,269,639$ \\
\hline
\end{tabular}

(Source: SHGs Profile of UDCRMS/IFAD, UKHRUL as on $30^{\text {th }}$ September 2007)

VII. Activities of IFAD in strengthening SHGs in Ukhrul District

Various kinds of workshop and skill upgradation trainings in weaving, food and fruit processing and entrepreneurship development programme were taken up by the IFAD in strengthening the SHGs.

Periodic assessment of the group was done every six months as per the assessment format developed by NABARD and funds were allotted to them, according to their performance. Weaker groups were identified and further capacity building or facilitation was done for improving the group performance. The target groups were thoroughly mobilized on the concept of SHG. The ultimate goals of the District for SHG movement were worked out in detail and the same was shared with the members. The poorest of the poor within the villages was covered in the first phase. Later on, the villagers themselves mobilized and the IFAD facilitated them on capacity building. The assistance provided by IFAD in promoting SHGs included financial assistance, technical assistance, human resources and training.

Table 3. Reasons for joining SHG by the respondents in the study area

\begin{tabular}{|l|l|l|l|}
\hline Sl.No. & Particulars & No. of respondents & Percentage \\
\hline 1 & For purposes of loan & 33 & 55.00 \\
\hline 2 & For promotion of savings & 27 & 45.00 \\
\hline 3 & For better social status & - & \\
\hline & Total & 60 & 100 \\
\hline
\end{tabular}

(Source: Field survey, $2009 \& 2010)$ 


\section{Reasons for joining SHGs}

The major aim of the SHGs is to promote savings and to obtain credit for both productive and consumption purposes. This is true because many people in the study area joined the SHGs for getting and promoting their personal savings. Table 3 shows that in the study area, a majority of the women (55\%) joined the SHGs for getting financial assistance, whereas the remaining 45 per cent of the respondents joined the SHGs for scaling up their savings. No respondent reported to have joined the SHGs for social, cultural and political purposes.

Table 4. Monthly income of the respondents before and after joining SHGs

\begin{tabular}{|l|l|l|l|l|l|}
\hline \multirow{3}{*}{ S1.No. } & \multicolumn{2}{|l|}{ Before joining SHGs } & After joining SHGs \\
\cline { 2 - 6 } & $\begin{array}{l}\text { Monthly income (in } \\
\text { Rs.) }\end{array}$ & $\begin{array}{l}\text { No. of } \\
\text { respondents }\end{array}$ & Percentage & $\begin{array}{l}\text { No. of } \\
\text { respondents }\end{array}$ & Percentage \\
\hline 1 & Less than 1000 & 36 & 60.00 & --- & --- \\
\hline 2 & $1000-2000$ & 22 & 37.00 & 32 & 53.33 \\
\hline 3 & $2000-3000$ & 02 & 3.00 & 18 & 30.00 \\
\hline 4 & $3000-4000$ & --- & --- & 10 & 16.67 \\
\hline & Total & 60 & 100 & 60 & 100 \\
\hline
\end{tabular}

(Source: Field survey, $2009 \& 2010$ )

\section{Income level of the members}

Income is the major determinant of the standard of living of the people. The income of the SHG members has increased after joining the SHGs. In Table 4 it is observed that before joining SHGs, 60 per cent of the members had a monthly income of less than Rs, 1000/- and 37 per cent of members had an income of Rs, 1000 to 2000/-, whereas two per cent of members had an income of Rs, 2000 to 3000/- per month.

After joining SHGs, 53.33 per cent of the members had a monthly income of Rs, 1000 to 2000/- and 30 per cent of members had an income of Rs, 2000 to 3000 per month, while 16.67 per cent of members had a monthly income of Rs, 3000 to 4000 .

It is clear that there has been a substantial increase in the income levels of members, in the lower income bracket, as well as in the middle and upper income bracket, after the members joined the SHGs. With an increased income, the members of the SHGs are independent to meet their personal expenditure, besides contributing to their household income.

Table 5. Levels of satisfaction by SHGs members in the functioning of IFAD in promoting SHGs

\begin{tabular}{|l|l|l|l|}
\hline Sl. No & Particulars & No. of respondents & Percentage \\
\hline 1 & Highly satisfied & 51 & 85.00 \\
\hline 2 & Satisfied & 09 & 15.00 \\
\hline 3 & Not satisfied & - & - \\
\hline 4 & Dissatisfied & - & - \\
\hline 5 & Highly dissatisfied & - & - \\
\hline & Total & 60 & 100 \\
\hline
\end{tabular}

(Source: Field survey, $2009 \& 2010$ )

\section{Level of satisfaction by SHGs members}

Table 5 shows the level of satisfaction by SHGs members in the functioning of IFAD in promoting SHGs. We can observe that 85 per cent of the SHGs members were highly satisfied, and 15 per cent of the SHGs members were satisfied. None of them expressed their dissatisfaction.

Table 6. Participation level of the SHGs members in the community activities

\begin{tabular}{|l|l|l|r|l|l|r|l|l|l|}
\hline \multirow{2}{*}{$\begin{array}{l}\text { Sl. } \\
\text { No. }\end{array}$} & Particulars & \multicolumn{6}{|l|}{ Before joining SHGs } & \multicolumn{2}{l|}{ After joining SHGs } \\
\cline { 3 - 10 } & Yes & No & $\begin{array}{l}\text { No. of } \\
\text { responses }\end{array}$ & $\%$ & Yes & No & $\begin{array}{l}\text { No. of } \\
\text { responses }\end{array}$ & $\%$ \\
\hline 1 & $\begin{array}{l}\text { Community } \\
\text { activities }\end{array}$ & - & $\checkmark$ & 60 & 100 & $\checkmark$ & - & 60 & 100 \\
\hline 2 & Public meetings & - & $\checkmark$ & 60 & 100 & $\checkmark$ & - & 60 & 100 \\
\hline 3 & $\begin{array}{l}\text { Training } \\
\text { programmes }\end{array}$ & - & $\checkmark$ & 60 & 100 & $\checkmark$ & - & 60 & 100 \\
\hline & Total & - & $\checkmark$ & 180 & 300 & $\checkmark$ & - & 180 & 300 \\
\hline
\end{tabular}

(Source: Field survey, $2009 \& 2010)$ 


\section{Level of participation}

Table 6 indicates that the level of participation in the community activities, public meetings and training programmes has increased. Before joining SHGs, it is clear that the members did not participate in any such social activities because they were not aware about their participation. After joining SHGs, it is noticed that all the members of SHG (100 per cent) participated in all such activities, at all levels.

\section{Conclusion}

Microfinance movement is initiated very late in the North Eastern part of India as compared to the rest of the countries. Although it is confounded by many regional complexities, there is a better and faster spread in its growth and development. The state of the SHG movement varies from state to state, and within states, from one district to another. In the context of Ukhrul District, in the traditional institution, women do not have much say in the decision making process and credit is considered as the men's domain. However, this position is slowly reversing by means of building the confidence of the individual members within the group through training, giving equal opportunity to be a leader in the group and ultimately giving them a chance to represent and share their opinion by formation of village Federation, Zonal Federation and the Apex body, known as UDWIM (Ukhrul District Women Institute of Micro Finance). It is believed that when the womenfolk are empowered, the family as a whole can lead a more healthy life by giving healthier food and accessing better health facilities through their rise in income level and can provide better education for their children. Ultimately, the SHGs activities can be more strengthened in almost all the groups.

\section{Suggestion}

More help and support is needed from the government, which will promote the SHGs to attain expected results. Some of the areas of support include the following:

- Despite a significant impact in the savings of women, SHGs are still lagging behind in some areas. Preparation of proper 'credit plan' based on the credit needs assessment and provision of adequate amount will be useful.

- In order to manage their accounts, thrust should be given to acquire book - keeping skills.

- Further, as part of financial services, financial counseling is required in order to diversify their livelihood portfolio and reduce the risk.

- The programme must aim at changes in the income generation activities; improve savings potential, borrowing capacity and their standard of living. In order to achieve these, SHGs should come out to provide consumption and production credit for initiating micro-enterprises.

\section{Acknowledgement}

Authors thank the University Grant Commission (UGC)/RGNF for their financial support for this study.

\section{References:}

[1] A low score, (Editorial column) The Hindu, http://www.thehindu.com/opinion/editorial/article2612528.ece [accessed 10 Nov $2011]$.

[2] NABARD, Status of Microfinance in India (2008-2009), http://www.nabard.org/pdf/reportfinancial/Full\%20Report.pdf

[3] NABARD, Annual Report 2010-2011.http://www.nabard.org/financialsreports.asp

[4] Shimray A.S.W. History of Tangkhul Nagas (Akansha Publication House, New Delhi, 2001). (79)

[5] Ibomcha S. Singh, Changes in the Socio-economic structure of Imphal District, during the plan period (1993), doctoral thesis, Manipur University, Manipur, (1996). 46-77.

[6] Khavul,S., Bruton,G. \&Wood,E, Informal family business in Africa, Entrepreneurship Theory and Practice, 33(6), 2009,12171236.

[7] UDCRMS/IFAD, Self Help Group Profile. Ukhrul District (30 Sept. 2007).

[8] U DCRMS/IFAD, Ukhrul District, Status Report (1999-2008)

[9] Vanita Kaul, Women and the wind of change (Gyan Publishing house, 2000).(163)

[10] Deepak Bhagat, Ahmed J.U. and Singaiah G. Microfinance in India: Issues and Challenges, Introduction, (2010), iii-viii.

[11] Grameen, Grameen Bank at ance, April http://www.grameeninfo.org/index.php/option=comcontent\&task=view\&id=752\&Itemid=16 [accessed 09 July 2010]

[12] Mayoux, L, Tracking the down side: Social capital, women's empowerment and micro-finance in Cameroon, Development and Change, (32), 2010, 421-450.

[13] Srinivasan N. Overview - Growth and consolidation, Microfinance India - State of the sector Report $2008,11$.

[14] World Bank (2007): "Microfinance in South Asia: Towards Financial Inclusion of the Poor", Washington D C: World Bank.

[15] Raghuram Rajan Committee, A Hundred Small Steps on Financial Sector Reforms, Planning Commission, Government of India. (2009).

[16] Maes, J., Foose, L. Microfinance services for very poor people: Promising Approaches from the Field and The US Law's Mandate to Reach Very Poor People: What Strategies are MFIs developing, and what do they mean for the rest of the Field? - A Practitioner Survey. (2006) Available at: http://www.microcreditsummit.org/papers/Workshops/6 MaesFoose.pdf 